\title{
Smart People In Smart City Analisis Sumber Daya Manusia Dalam Rangka Mewujudkan Kota Tangerang Selatan Yang Cerdas
}

\author{
${ }^{1}$ Irwan Suhartono, Ibnu Sina \\ Dosen Fakultas Ekonomi Universitas Pamulang \\ Email: ${ }^{1}$ dosen01560@unpam.ac.id
}

\begin{abstract}
ABSTRAK
Konsep Smart City yang rencana akan didesain di wilayah Tangerang Selatan merupakan sebuah konsep kota cerdas yang dapat membantu masyarakat mengelola sumber daya yang ada dengan effisien dan memberikan informasi yang tepat kepada masyarakat atau lembaga dalam melakukan kegiatannya atau pun mengantisipasi kejadian yang tak terduga sebelumnya. Konsep Smart City kini menjadi impian kotaTangerang Selatan, dianggap sebagai solusi dalam mengatasi kemacetan yang merayap, sampah yang berserakan, ataupun pemantau kondisi lingkungan di suatu tempat yang menarik. Sebuah kota dengan dukungan teknologi pintar dalam menunjang aktivitas sehari-hari tentu akan semakin memudahkan manusia. Hanya saja, konsep Smart City Tangerang Selatan ini tampaknya masih harus didukung dengan pola pikir dan tindakan nyata manusia modern di Indonesia. Kesadaran akan lingkungan, pemanfaatan teknologi yang maksimal, serta kesadaran pentingnya pola hidup "cerdas" adalah hal- hal yang perlu diperhatikan juga. Merupakan sesuatu yang ironis, jika sebuah kota Tangerang Selatan mendapat predikat Smart City, namun masih membuang sampah sembarangan, merusak atau mengambil fasilitas, serta hal hal lainnya yang sifatnya negatif. Terlepas dari itu, Smart City Tangerang Selatan tampaknya bukanlah sebuah angan-angan belaka. Apalagi jika Smart City Tangerang Selatan ini didukung dengan cara berpikir dan bersikap yang cerdas. Untuk mewujudkan Smart City di Tangerang Selatan agar konsep Smart City tersebut dapat berjalan dengan baik dan sesuai dengan konsep Smart City yang diinginkan kota- kota di Indonesia, yaitu Biaya \& Sumber Daya Manusia (SDM). Masyarakat yang mampu mengembangkan sumberdaya alam lingkungan kota, membentuk karakter pola pikir maupun perilaku yang positif menerima perbedaan yang berkembang, dan memelihara fasilitas maupun infrastrukrur kota, maka mereka dikategorikan sebagai Smart People. Penelitian ini dilaksanakan 7 Kecamatan di wilayah Tangerang Selatan. Pemilihan kecamatan berdasarkan arahan dari kedinasan atau instansi tertentu di wilayah Pemkot Tangerang Selatan. Tujuan dari penelitian ini adalah untuk mengajak dan memotivasi masyarakat di Tangerang Selatan agar dapat memahami maksud dan tujuan yang sesungguhnya dalam hal berfikir dan bersikap ke arah yang lebih baik sesuai dengan tatanan dan tuntunan yang bersifat kebaikan (goodness morality) guna tercapainya impian agar kota cerdas Tangerang Selatan dapat tercapai. Tahapan yang dilakukan dalam penelitian ini adalah (1) identifikasi wilayah yang dijadikan model penelitian (2) koordinasi dengan instansi atau lembaga yang terkait (3) komunikasi langsung dengan masyarakat.
\end{abstract}




\section{Kata Kunci : Smart City, Smart People, Sumber Daya Manusia, Serpong}

\section{PENDAHULUAN}

Konsep "Smart City" atau kota cerdas kini mulai diterapkan di berbagai kota besar di Indonesia. Konsep ini merupakan impian bagi kota-kota di Indonesia karena diyakini bisa menyelesaikan berbagai masalah perkotaan seperti kemacetan, penumpukan sampah, dan keamanan warga kota. Konsep kota cerdas ini mengetengahkan sebuah tatanan kota yang memudahkan masyarakat

untuk mendapatkan informasi secara cepat dan tepat. Beberapa kota besar di Indonesia yang sudah menerapkan konsep "Smart City" ini antara lain Jakarta, Bandung, Surabaya, Yogyakarta, dan Malang. Dalam "Konferensi Smart City" yang diselenggarakan di kampus Institut Teknologi

Bandung (ITB) baru- baru ini, terungkap bahwa minat masyarakat Indonesia terhadap teknologi, terutama teknologi informasi, kini sangat tinggi.

Mahfudz Siddiq, ketua Komisi I DPR yang membawahi bidang pertahanan, luar negeri, komunikasi dan informatika serta intelijen, mengatakan bahwa survey menunjukkan pengguna internet di Indonesia saat ini mencapai lebih dari 80 juta orang. Dari jumlah tersebut, 87 persen memanfaatkan Internet untuk mengakses media sosial.Jumlah pengguna kartu telepon seluler atau SIM card yang beredar pun melampaui jumlah penduduk Indonesia, yaitu 260 juta keping kartu. Keterampilan menggunakan fasilitas internet dan teknologi informasi lain sudah sedemikian melekat dengan keseharian masyarakat Indonesia. Fenomena ini merupakan salah satu modal utama penciptaan kota cerdas atau "Smart City".

Tahun 2016, Kementerian Komunikasi dan Informatika menargetkan pengguna Internet di Indonesia mencapai 150 juta orang. Dan yang menarik, berdasarkan survei, 51 persen pengguna Internet itu adalah wanita dan 80 persen dari pengguna itu umumnya mereka yang berusia muda," ujarnya. Budayawan Yasraf Amir Piliang menilai pembentukan kota cerdas tidak terlepas dari "smart society" atau masyarakat yang cerdas. Menurut Yasraf, penggunaan teknologi dalam kehidupan masyarakat sehari-hari bukan merupakan satu-satunya syarat untuk

penerapan "smart city”.Ia mengatakan bahwa masyarakat harus memahami betul apa peran teknologi dalam membangun sebuah masyarakat, yang salah satu diantaranya adalah kesadaran bahwa kita hidup dalam sebuah jejaring, yang merupakan esensi dari sebuah masyarakat yang cerdas.

Komponen pembentuk terwujudnya Smart City adalah 1) Smart Governance, 2) Smart environment, 3) Smart Living, 4) Smart Mobility, 5) Smart Economy, dan 6) Smart People. Hal ini bisa dicermati pada diagram fishbone di bawah ini. 


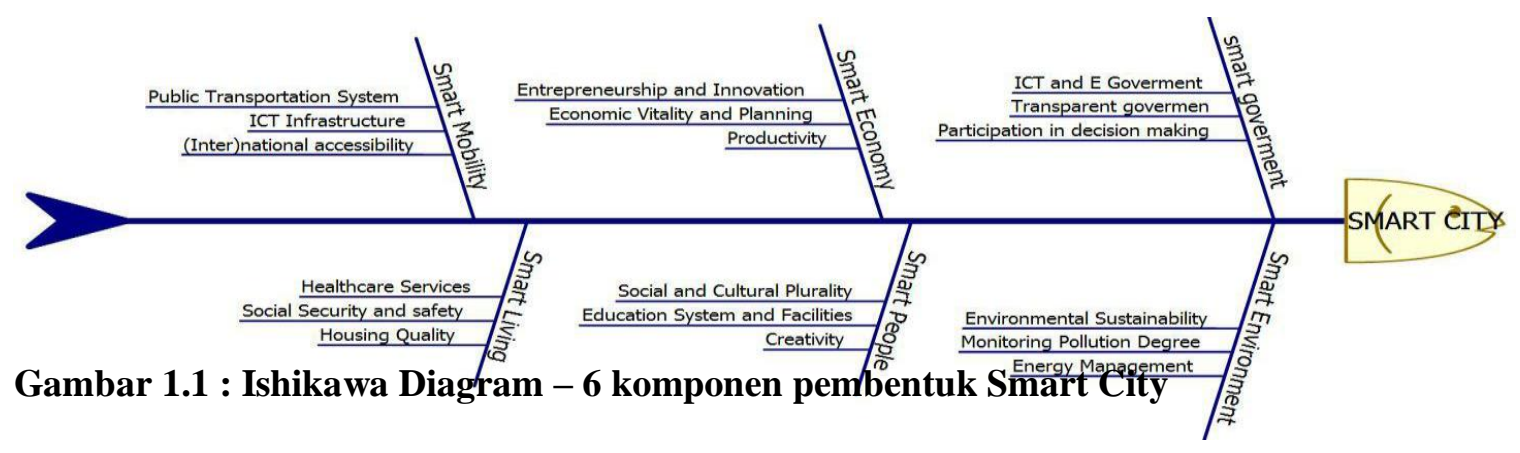

\section{TINJAUAN PUSTAKA \\ Ilmu Sosial Budaya}

Berikut ini merupakan pembahasan tentang sikap dan perilaku masyarakat terhadap perubahan sosial-budaya, perilaku masyarakat dalam perubahan sosial budaya di era global, perilaku masyarakat dalam perubahan sosial budaya di era globalisasi, perilaku masyarakat terhadap perubahan sosial budaya, perilaku masyarakat dalam menyikapi perubahan sosial budaya. Pada umumnya masyarakat lebih menyukai kehidupan mereka berjalan seperti biasa. Sudah menjadi sifat khas manusia untuk mempertahankan hal-hal yang enak dan nyaman. Karena itu, hal-hal baru yang dapat menimbulkan perubahan pada awalnya cenderung ditolak. Di sini kamu sendiri bisa memberi contoh. Orang tuamu mungkin menolak jika kamu meminta sebuah handphonebaru. Bagi mereka, kamu belum cukup dewasa untuk menggunakan alat komunikasi tersebut. Di sini kebanyakan orang lupa bahwa alat komunikasi seperti handphone dibutuhkan sematamata sebagai alat penghubung antarmanusia dalam berkomunikasi, dan tidak ada hubungan dengan kedewasaan seseorang.

Tentu seorang anak balita tidak mungkin menggunakan handphone, karena belum mempu menguasai dan mengoperasikan alat tersebut.

Masyarakat umumnya enggan mengikuti perubahan, terutama perubahanperubahan sosial dan budaya yang melibatkan perubahan kebiasaan, lembaga sosial, nilai, dankepercayaan.

Meskipun demikian, harus dikatakan bahwa tidak semua hal baru atau perubahan mendapat tentangan secara luas dari masyarakat. Ada sebagaian masyarakat dengan karakteristik tertentu memang sangat terbuka pada perubahan. Misalnya, masyarakat yang heterogen, masyarakat dengan tingkat pendidikan dan kontak sosial dengan kebudayaan lain sangat terbuka, masyarakat di daerah 
perkotaan, dan sebagainya. Sementara

itu, masyarakat dengan karakteristik yang cenderung menolak perubahan akan menyebabkan lambat atau tidak mulusnya sebuah perubahan sosial. Karena perubahan sosial dan budaya tidak bisa dihindari, baik masyarakat yang terbuka pada perubahan maupun yang cenderung menolak perubahan harus dapat diakomodasi kepentingannya.

\section{Ilmu Pendidikan}

Pendidikan

pada

hakekatnya adalah usaha sadar dan terencana untuk mewujudkan suasana belajar dan proses pembelajaran agar peserta didik secara aktif mengembangkan potensi dirinya untuk memiliki kekuatan spiritual keagamaan, pengendalian diri, kepribadian, kecerdasan, ahklak mulia, serta keterampilan yang diperlukan dirinya masyarakat, bangsa dan negara. Pendidikan nasional adalah pendidikan yang berdasarkan Pancasila dan UUD 1945 yang berakar pada nilai-nilai agama, kebudayaan nasional Indonesia, dan tanggap terhadap perubahan zaman. Fungsi dan tujuan pendidikan nasional tercantum dalam UU No. 20tahun 2003 bab II pasal 3 .

Jalur pendidikan adalah wahana yang dilalui peserta didik untuk mengembangkan potensi diri dalam suatu proses pendidikan yang sesuai dengan tujuan pendidikan. Dalam UU No. 20 tahun 2003 Pasal 13 ayat 1 dinyatakan bahwa jalur pendidikan terdiri dari pendidikan formal, non-formal dan informal.

\section{Perilaku}

Secara umum pengertian perilaku adalah tindakan dari makhluk hidup itu sendiri yang mempunyai bentangan arti yang sangat luas antara lain : berjalan, berbicara, menangis, tertawa, bekerja, kuliah, menulis, membaca, dan sebagainya. Dari sisi kemanusiaan, perilaku manusia adalah semua kegiatan manusia, baik yang diobservasi langsung maupun yang tidak langsung oleh pihak pengamat (Notoatmodjo, 2003). Pengertian perilaku manusia dapat dibatasi sebagai keadaan jiwa untuk berpendapat, berfikir, bersikap, dan lain sebagainya yang merupakan refleksi dari berbagai macam aspek, baik fisik maupun non fisik. Perilaku juga diartikan sebagai suatu reaksi internal seseorang terhadap lingkungannya, reaksi yang dimaksud digolongkan menjadi dua, yakni :
a. Bentuk pasif (tanpa tindakan nyata atau konkrit),
b. Dalam bentuk aktif (menunjukkan tindakan konkrit)

\section{HASIL PENELITIAN}

1. Pendidikan Formal

Pendidikan

formal 
merupakan pendidikan yang diselenggarakan di sekolahsekolah pada umumnya. Jalur pendidikan ini mempunyai jenjang pendidikan yang jelas, mulai dari pendidikan dasar, pendidikan menengah, sampai pendidikan tinggi.

\section{Pendidikan Non Formal}

Pendidikan nonformal adalah jalur pendidikan di luar pendidikan formal yang dapat dilaksanakan secara terstruktur dan berjenjang. Pendidikan nonformal paling banyak terdapat pada usia dini, serta pendidikan dasar, adalah TPA, atau Taman Pendidikan Al Quran,yang banyak terdapat di Masjid dan Sekolah Minggu, yang terdapat di semua Gereja. Selain itu, ada juga berbagai kursus, diantaranya kursus musik, bimbingan belajar dan sebagainya.

\section{a. Sasaran}

Pendidikan

nonformal

diselenggarakan bagi warga masyarakat yang memerlukan layanan pendidikan yang berfungsi sebagai pengganti, penambah, dan/atau pelengkap pendidikan formal dalam rangka mendukung pendidikan sepanjang hayat.

\section{b. Fungsi}

Pendidikan nonformal mengembangkan potensi peserta didik dengan penekanan pada penguasaan pengetahuan dan keterampilan fungsional serta pengembangan sikap dan kepribadian profesional.

\section{c. Jenis}

Pendidikan

nonformal meliputi pendidikan kecakapan hidup, pendidikan anak usia dini, pendidikan kepemudaan, pendidikan pemberdayaan

perempuan, pendidikan keaksaraan, pendidikan keterampilan dan pelatihan kerja.

Pendidikan kesetaraan meliputi Paket A, Paket B dan Paket C, serta pendidikan lain yang ditujukan untuk mengembangkan

kemampuan peserta didik seperti: Pusat Kegiatan Belajar Masyarakat (PKBM), lembaga kursus, lembaga pelatihan, kelompok belajar, majelis taklim, sanggar, dan lain sebagainya, serta pendidikan lain yang ditujukan untuk mengembangkan

kemampuan peserta didik.

\section{Pendidikan informal}

Pendidikan informal adalah jalur pendidikan keluarga dan lingkungan berbentuk kegiatan belajar secara mandiri yang dilakukan secara sadar dan bertanggung jawab. Hasil 
pendidikan informal diakui sama dengan pendidikan formal dan nonformal setelah peserta didik lulus ujian sesuai dengan standar nasional pendidikan.

Alasan pemerintah mengagas pendidikan informal adalah:

- Pendidikan dimulai dari keluarga

- Informal diundangkan juga karena untuk mencapai tujuan pendidikan nasonal dimulai dari keluarga

- Homeschooling: pendidikan formal tapi dilaksanakan secara informal.

- Anak harus dididik dari lahir

Dalam pembahasan kali ini kami akan secara khusus mengenal sikap dan perilaku masyarakat terhadap setiap perubahan sosial dan budaya. Pemahaman ini akan sangat berguna untuk mengamati dan memahami sikap-sikap masyarakat dalam menanggapi setiap perubahan sosial dan budaya. Perubahan sosial dan budaya selain disebabkan oleh berbagai kebutuhan hidup yang dihadapi, juga disebabkan oleh pengaruh atau masuknya unsur kebudayaan baru atau asing. Ada masyarakat yang cenderung mempertahankan keadaan sosial budaya yang sudah ada. Mereka melakukan demikian karena unsur yang mereka pertahankan sangat berguna bagi masyarakatnya atau berguna sebagai pedoman hidup bersama. Maka, jika terjadi perubahan justru akan menggoyahkan keseimbangan sistem sosial. Misalnya, beberapa siswa Sekolah Menengah Pertama (SMP) membentuk sebuah kelompok teman sebaya (peer group). Kelompok ini biasanya melakukan banyak hal secara bersama-sama, misalnya mengerjakan tugas yang diberikan guru, melakukan penelitian sederhana, dan sebagainya.

Dalam perkembangannya, kebiasaan beberapa siswa yang merokok menyebabkan siswasiswa lain pun ikut merokok. Mereka bahkan mulai lupa akan misi awal pembentukan kelompok mereka dan mulai malas-malasan ke sekolah. Mereka juga sering terlibat tawuran dengan siswa dari sekolah lain. Tentu masyarakat setempat kecewa dengan cara hidup mahasiswa semacam ini. Mereka tidak mungkin akan bisa mengubah cara dan pandangan hidup masyarakat desa. Masyarakat desa bahkan mengecam cara hidup mahasiswa ini yang bertentangan dengan nilai moral dan agama. Ini adalah contoh sederhana bagaimana masyarakat memilih mempertahankan nilai- nilai sosial dan kebudayaannya daripada mengikuti perubahan cara hidup sebagaimana ditunjukkan para mahasiswa. Di sini tampak sekali kecenderungan kuat dalam 
masyarakat

untuk

mempertahankan beberapa

unsur kebudayaannya dan

menolak

unsur-unsur

kebudayaan yang berasal dari

kebudayaan lain.

DAFTAR PUSTAKA

Arthur, Diane., Fundamentals of

Human

Resources

Management.,

Publisher:

American

Association

Management, New York., 2004

Camille Rosenthal-Sabroux., Renata

Paola Dameri, Smart City:

How to Create Public and

Economic Value with High

Technology in Urban Space.,

New York : Springer

International Switzerland., 2014

Dwivedi., Yogesh K., Advances in Smart Cities: Smarter People, Governance, and Solutions., Publisher : Taylor \& Francis Incorporated, 2017

Myles., Gareth D., Public Economics., Publisher :
Cambridge University Press., 1995.

Prayitno, Prof. Dr., Dasar Teori dan Praksis Pendidikan., Penerbit : Grasindo 2009

Rahardiansah, Trubus., Perilaku manusia dalam perspektif struktural, sosial, dan kultural., Penerbit Universitas Trisakti, 2011

Skinner., B. F., Ilmu Pengetahuan dan Perilaku Manusia, Penerbit : Pustaka Pelajar, Yogyakarta, 2011

Sunarsi, D. (2018). Analisis Motivasi Kerja Tenaga Pendidik Sukarela Pada Pusat Kegiatan Belajar Masyarakat (PKBM) Bimasda Kota Tangerang Selatan. Kreatif: Jurnal Ilmiah Prodi Manajemen Universitas Pamulang, 6(2), 53-65.

Sunarsi, D. (2018). Pengaruh Gaya Kepemimpinan, Motivasi Dan Disiplin Kerja Terhadap Kinerja Pendidik Yayasan Marvin. Inovasi, 5(1), 1-18. 


\section{PANDUAN SINGKAT BAGI PENULIS JURNAL SDM JENIUS}

Panduan penulisan ini dimaksudkan untuk menyeragamkan bentuk penulisan karya ilmiah yang dikirim penulis ke redaksi Jurnal Jenius, dengan panduan penulisan sebagai berikut :

1. Naskah ditulis dalam Bahasa Indonesia dengan Abstrak Bahasa Indonesia dalam bentuk Font 12" dengan ukuran 1 Spasi dengan intisari tidak lebih dari 250 kata disertai 3 atau 4 kata kunci (keyword).

Naskah berupa Softcopy program MS Word maksimal 25 Halaman termasuk tabel dan gambar, spasi 1.

2. Sistematika penulisan disusun dengan urutan sebagai berikut :

a) Judul, nama dan alamat email penulis/peneliti tunggal.

b) Abstrak dan intisari, keyword dan kata kunci, dibuat dengan 1 kolom.

c) Batang Tubuh :

1). Pendahuluan, termasuk didalamnya intisari permasalahan

2). Perumusan Masalah

3). Tujuan Penelitian

4). Landasan teori termasuk didalamnya hipotesis dan kerangka Pemikiran

5). Metode Penelitian

6). Hasil dan Pembahasan

7). Kesimpulan

8). Daftar Pustaka

9). Seluruh isi tersebut di buat dengan 2 kolom

3. Judul ditulis dalam bentuk font Times New Roman 12" dengan huruf besar kecil dicetak tebal dan ditempatkan ditengah halaman,, serta tidak lebih dari 18 kata.

4. Tulisan karya ilmiah dalam bentuk font Times New Roman 12" dengan ukuran spasi 1,0 spasi dalam bentuk kolom.

5. Gambar diberi nomor dan keterangan, sedangkan tabel diberi nomor dan keterangan diatasnya.

6. Penulisan persamaan matematika yang terdapat pada halaman naskah hendaknya menggunakan equation editor.

7. Daftar pustaka hanya memuat literature yang dirujuk dalam keterangan dan dicantumkan pada bagian akhir naskah dilakukan dengan memberikan nomor.

8. Margin atas dan kiri $4 \mathrm{~cm}$, kanan dan bawah $3 \mathrm{~cm}$, dan ukuran kertas A4.

9. Email Redaksi : jurnalsdm.unpam@gmail.com/denoksunarsi@gmail.com. 